\title{
The Relationship among Corporate Social Responsibility, Consumer-Company Identification, Brand Prestige, and Purchase Intention
}

\author{
Mei-Hua Chen ${ }^{1}$, Pei-Ni Tai ${ }^{1} \&$ Bryan H. Chen ${ }^{1}$ \\ ${ }^{1}$ Department of Finance, National Changhua University of Education, Taiwan \\ Correspondence: Pei-Ni Tai, Department of Finance, National Changhua University of Education, Changhua City, \\ Taiwan. Tel: 886-9-2150-3867. E-mail: gracetai0602@gmail.com
}

Received: June 26, 2015 Accepted: August 25, 2015 Online Published: September 29, 2015

doi:10.5539/ijms.v7n5p33 URL: http://dx.doi.org/10.5539/ijms.v7n5p33

\begin{abstract}
This study analyzes relationships between corporate social responsibility, consumer-company identification, brand prestige, and purchase intention. A self-report survey yields data for 252 college students. After confirming reliability and validity of survey questionnaire, the structural equation modeling was used for tests the model. Results were summarized as follows: (a) CSR image has a significant positive effect on brand prestige and consumer-company identification. (b) Brand prestige has a significant positive effect on consumer-company identification. (c) Consumer-company identification has a significant positive effect on purchase behavior. (d) Consumer-company identification mediates the effect of CSR image on consumers' purchase intention. This outcome reveals that CSR image creates consumers' identification with the company, which may enhance consumers' purchase intention.
\end{abstract}

Keywords: corporate social responsibility, consumer-company identification, brand prestige, purchase intention

\section{Introduction}

The last two decades have seen growing important placed on research in corporate social responsibility (CSR) (Carroll \& Shabana, 2010; Malik, 2015). In recent years, CSR is getting considerable attention not only from scholars but also from consumers (Park, Lee, \& Kim, 2014). Researches indicate that CSR can increase brand value, bolster consumer loyalty, and escalate sales revenue (Jeong, Paek, \& Lee, 2013; Lee, Lau, \& Cheng, 2013). Moreover, CSR can also facilitate the company to differentiate their products from industry competitors and establish a clean-cut brand prestige (Malik, 2015). In simple terms, a firm can boost their sales and profitability through practicing CSR initiatives.

An increasing number of consumers have made their purchase decisions by observing the company's CSR practices or ethical behaviors (Davies, Lee, \& Ahonkhai, 2012; Grimmer \& Bingham, 2013). When conscientious consumers find out that the company with a good CSR reputation, they tend to reward the company (e.g., Carrotmob, word-of-mouth, buying products); once consumers discover that the company was "doing badly", they would like to adopt punish behavior to reflect consumers' indignation (e.g., complain, boycott, and protest) (Sweetin, Knowles, Summey, \& McQueen, 2013). Not only had consumers spread burnished or tarnished word of mouth, they had also empowered consumer movement in an enthusiastic way. As Smith (1995) pointed out, we are now living in the "ethics era".

Nevertheless, even though researchers addressed those benefits the companies can obtain from practicing CSR. When it comes to consumers' purchasing behavior, these studies appear to contradict one another; some have been suggested that CSR has a positive impact on consumers' purchase behavior (Lee \& Lee, 2015; Mohr \& Webb, 2005), and some addressed that CSR only has minor impact (Mohr, Webb, \& Harris, 2001). However, the effect of CSR still remains unclear.

Over the past 20 years, there are numerous corporate social irresponsibility events (e.g., gutter oil, contaminated food) in Taiwan. Dishonest enterprises made a fortune by selling conscienceless goods. It triggered Taiwanese consumers to organize a boycott activism spontaneously. Besides, more and more consumers chose buycotting to replace boycotting, which reflected that "Carrotmob" would be a novel form of future ethical consumption (Hoffmann \& Hutter, 2012). Since consumers have the power to choose either carrot or stick, it is important to 
understand what factors affect Taiwanese consumers' purchase behavior.

This research tends to investigate how do CSR image, brand prestige, and consumer-company identification affects consumers' purchase intention.

\section{Literature Review}

Due to product diversification and consumer awareness in today's product market, consumers change their loyalty easily. More and more companies trying to build long-term relationships with consumers. Corporate social responsibility became an effective marketing strategy that companies using to enhance their image, reputation, identification, and purchase intention (Mohr \& Webb, 2005; Lee \& Lee, 2015; Saeidia, Sofiana, Saeidia, Saeidia, \& Saaeidi, 2015). Several studies have suggested that CSR could not only increase brand prestige, but also mediate the relationship between CSR and brand performance (Lai, Chiu, Yang, \& Pai, 2010; Saeidia et al., 2015). Based on the literature review, the present study address 6 hypotheses, the theoretical model (see Figure 1) are proposed.

Steenkamp, Batra and Alden (2003) defined brand prestige as "the relatively high status of product positioning associated with a brand" (as cited in Baek, Kim \& Yu, 2010). Helm (2011:657) defines corporate reputation "is a socially shared impression - a collective construct—-because it relies on an individual's perception of how other people view the firm". A growing number of companies adopted CSR initiatives to increase their prestige (Curras-Perez, Binge-Alcaniz \& Alvarado-Herrera, 2009; Lai et al., 2010; Pomering \& Johnson, 2009). Park et al (2014) adapted Carroll's four CSR responsibilities (economic, legal, ethical, and philanthropic) to test the relationship among CSR responsibility, consumer trust, and corporate reputation, found out that economic and legal CSR initiatives had a direct positive effect on corporate reputation. Moreover, Saeidia et al. (2015) found that reputation and competitive advantage mediating the relationship between CSR and firm performance. Hence, it is hypothesized that:

H1. CSR image has a positive influence on brand prestige.

In order to maintain their customers, the company needs to make consumers identified with them; and further, consumers will support the company. This process was deemed consumer-company identification, which is, how consumers defined themselves, based on the role as being a consumer of the company and perceived organizational identity (Curras-Perez et al., 2009; Einwiller, Fedorikhin, Johnson, \& Kamins, 2006). Bhattacharya and Sen (2003, p. 77) defines consumer-company identification as "the relationships are based on consumers' identification with the companies that help them satisfy one or more key self-definitional needs". Empirical studies show a positive relationship between CSR image and consumer-company identification (Lii \& Lee, 2012; Marin \& Ruiz, 2007). Hence, it is proposed:

H2. CSR image has a positive influence on consumer-company identification.

Johan and Ulf (2007) suggest that CSR image has a positive impact on consumers' purchase intention. Lee and Shin (2010) noted that corporate social contribution and local community contribution affect consumers' purchase intention. Moreover, Sweetin et al. (2013) provide an interesting research, found that consumers had higher purchase intention to social responsible company than socially irresponsible company. On the contrary, Oberseder, Schlegelmilch and Gruber (2011) find that though consumers have positive attitude toward socially responsible companies, it may not affect their actual purchase behavior. The effect of CSR image remains unclear. Thus, it is hypothesized that:

H3. CSR image has a positive influence on consumer's purchase intention.

Kuenzel and Halliday (2008) confirm that brand prestige positively affects consumers' brand identification. Also, Kuenzel and Halliday (2010) address that consumers have a higher level of brand identification when they perceive a reputable brand. Moreover, Lii and Lee (2012) testing CSR reputation (prestige) as a moderator of the relationship among CSR initiatives, consumer-company identification, and brand attitude, found that CSR initiatives have a significant effect on consumer-company identification and brand attitude. Hence, it is proposed:

H4. Brand prestige has a positive influence on consumer-company identification.

Elbedweihy and Jayawardhena (2014) summarize that brand prestige as an important antecedent of consumer's purchase intention. Tseng and Chen (2008) confirm that the higher consumer perceived brand prestige, the higher consumer purchase intention. Furthermore, Moslehpour, Pham, and Yumnu (2014) found that perceived brand prestige positively affects consumer purchase likelihood. Thus, it is hypothesized that:

H5. Brand prestige has a positive influence on consumer's purchase intention. 
$\mathrm{Wu}$ and Tsai (2007) found that consumer-company identification positively influences consumer purchase intention. Curras-Perez et al. (2009) and Bigne-Alcaniz, Curras-Perez, Ruiz-Mafe and Sanz-Bla (2010) also confirm that consumer-company identification positively affects consumer's purchase intention. Moreover, Perez (2009) reports that company attitude and company commitment are the mediators between CSR-based consumer-company identification and purchase intention. Hence, it is proposed:

H6. Consumer-company identification has a positive influence on consumer's purchase intention.

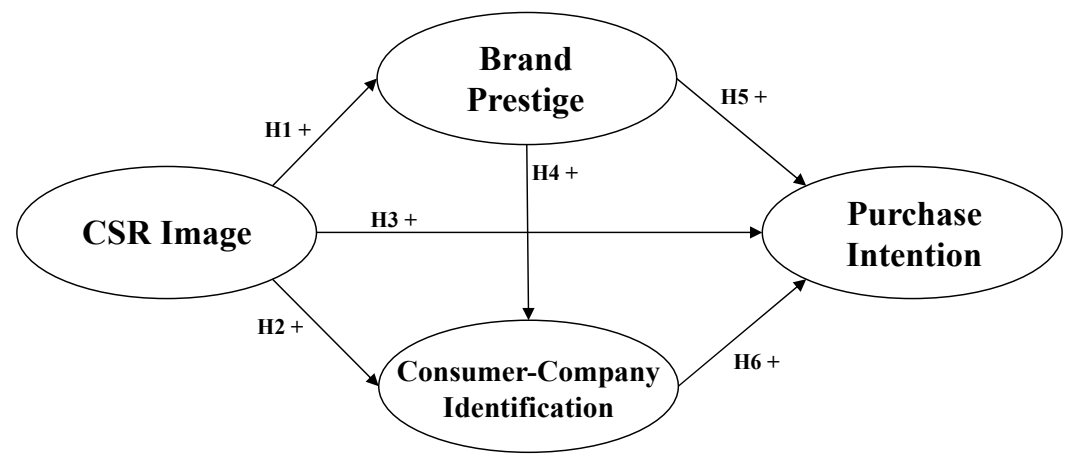

Figure 1. Conceptual model

\section{Methodology}

The sample consisted of undergraduate college students who were recruited via convenience sampling in central Taiwan. The populations of general consumers were hard to define, so this research focuses on college students as target consumers who had goods shopping experiences. Moreover, marketers regard college students as a major target group to expand and keep (Tarnanidis, Owusu-Frimpong, Nwankwo, \& Omar, 2015). Thus, the sampling of college students met the purpose of this study. Participants answered survey questionnaire of the scales for CSR image, consumer-company identification, brand prestige, and purchase intention. The respondents rated the issues on a scale from one to seven where 1 represented "strongly disagree" and 7 represented "strongly agree". Those variables were defined as follows.

\subsection{Instruments}

The CSR image scale (4 items) was adapted and modified from a scale by Curras-Perez et al. (2009), the scale received high internal reliability (Cronbach's $\alpha=.871$ ). The consumer-company identification (5 items) scale was adapted and modified from a scale by Perez, Rodriguez and Bosque (2013), the scale received high internal reliability (Cronbach's $\alpha=.942$ ). The brand prestige scale was adapted and modified from Mael and Ashforth's (1992) three-item scale, the scale received high internal reliability (Cronbach's $\alpha=.841$ ). Finally, the purchase intention was adapted and modified from Putrevu and Lord's (1994) three-item scale, the scale received high internal reliability (Cronbach's $\alpha=.860$ ).

\section{Results}

A total of 280 students participated in this research. Twenty-eight $(0.1 \%)$ participants did not provide full data and were removed from the sample. The total effective sample is 252 . While $49 \%(n=124)$ of the sample were male, $51 \%(\mathrm{n}=128)$ were female.

\subsection{CFA}

Amos 22.0 was used to confirm the structure model relationships through confirmatory factor analyses (CFA). During the fit process through CFA, three items (CSR1, CCID1, and CCID2) were eliminated. The CFA results showed a good fit of the confirmatory measurement model $\left(\chi_{(48)}^{2}=83.002, p=.001 ; \chi^{2} / d f=1.729 ; \mathrm{NFI}=.961\right.$; $\mathrm{CFI}=.983$; RMSEA $=.054)$. Table 1 displayed the indicators calculated to verify properties and the main goodness-of-fit indexes.

\subsection{Descriptive Statistics}

Table 2 showed the profiles of participants. Descriptive statistics concerning CSR image, consumer-company identification, brand prestige, and purchase intention were presented in Table 3. As shown, the mean value of CSR image was $4.28(\mathrm{SD}=1.15)$; that for the consumer-company identification was $4.50(\mathrm{SD}=0.08)$; that for brand prestige was $5.60(\mathrm{SD}=0.96)$; and the value for purchase intention was $4.69(\mathrm{SD}=1.25)$. The Pearson 
product moment correlations between variables were also displayed in Table 3 . The correlations between all constructs are, as expected, positive at a significant level.

\subsection{Estimation of Structural Relationships}

Full model analysis was performed using the maximum likelihood test and structural relationships. Parameter estimates were accessed using SEM, and the Cronbach's coefficient was set at $\alpha=.05$. To begin with the offending estimates were used to examine whether (a) the estimated coefficients were larger or close to one (typically with a threshold of .95) or (b) the standard error was overly large or assumed a negative value. The offending variance in this study was fitted statistic requirement. Thus, the fit of indicator to each construction could be further examined.

Table 1. Confirmatory factor analysis

\begin{tabular}{|c|c|c|c|c|c|}
\hline Factor & Item & Loading & Standard Errors & $\mathrm{CR}$ & AVE \\
\hline \multirow[t]{4}{*}{ CSR image (CSR) } & & & & & .728 \\
\hline & $\operatorname{csr} 2$ & .817 & .055 & 16.222 & \\
\hline & $\operatorname{csr} 3$ & .801 & .052 & 16.711 & \\
\hline & $\operatorname{csr} 4$ & .939 & & & \\
\hline \multirow[t]{4}{*}{ C-C identification (CCID) } & & & & & .763 \\
\hline & cci3 & .925 & .055 & 16.680 & \\
\hline & cci4 & .886 & .059 & 16.714 & \\
\hline & cci5 & .808 & & & \\
\hline \multirow[t]{4}{*}{ Brand prestige (BPR) } & & & & & .639 \\
\hline & bpr1 & .800 & .104 & 11.672 & \\
\hline & bpr2 & .879 & .112 & 12.342 & \\
\hline & bpr3 & .713 & & & \\
\hline \multirow[t]{4}{*}{ Purchase Intention (PIN) } & & & & & .679 \\
\hline & $\operatorname{pin} 1$ & .833 & .050 & 16.177 & \\
\hline & $\operatorname{pin} 2$ & .773 & .051 & 14.456 & \\
\hline & pin 3 & .865 & & & \\
\hline
\end{tabular}

Table 2. Descriptive statistics of participants

\begin{tabular}{lll}
\hline & $\mathrm{N}$ & Valid percentage (\%) \\
\hline Gender & & \\
Male & 124 & 49 \\
Female & 128 & 51 \\
Monthly allowance & & \\
NT\$2,001-4,000 & 68 & 27.0 \\
NT\$4,001-6,000 & 69 & 27.4 \\
NT\$6,001-8,000 & 64 & 25.4 \\
above NT\$8,000 & 51 & 20.2 \\
\hline
\end{tabular}

Table 3. Descriptive statistics of variables

\begin{tabular}{llllllll}
\hline & Number of items & Cronbach's $\alpha$ & Mean & SD & A & B & C \\
\hline A) CSR & 3 & .887 & 4.28 & 1.15 & 1.00 & & \\
B) CCID & 3 & .901 & 4.50 & 0.08 & $.42 * *$ & 1.00 & \\
C) BPR & 3 & .841 & 5.60 & 0.96 & $.57 * *$ & $.53 * *$ \\
D) PIN & 3 & .860 & 4.69 & 1.25 & $.38^{* *}$ & $.90 * *$ & $.46 * *$ \\
\hline
\end{tabular}

$* * p<.01$.

The square multiple correlations and the index fit of the model were shown in Table 4 and 5 respectively. As can be seen, all fit indices were within a satisfactory range. The fit indices were (a) absolute fit measures of the SRMR (<.05), RMSEA (<.08), (b) relative fit measures of the non-normed fit index (NNFI >.95), the CFI $(>.95)$, and (c) parsimonious fit measures of the parsimony normed fit index (PNFI >.50), the parsimony GFI (PGFI $>.50)$, and $\chi^{2} / d f(<3.0)$. Hence, these indices suggest a good model fit in this study. 
Table 4. Index of the fit of the model

\begin{tabular}{llll}
\hline Index & Accept Value & Value & Results \\
\hline$\chi^{2}$ & & 83.002 & \\
Degrees of freedom & - & 48 & \\
Absolute fit measures & & & \\
SRMR & $<0.05$ & .0426 & Accepted \\
RMSEA & $<0.08$ & .054 & Accepted \\
Relative fit measures & & & \\
NNFI & $>.95$ & .977 & Accepted \\
CFI & $>.95$ & .983 & Accepted \\
Parsimonious fir measures & & & \\
PNFI & $>.50$ & .961 & Accepted \\
PGFI & $>.50$ & .583 & Accepted \\
$\chi^{2}$ & $<3.0$ & 1.729 & Accepted \\
\hline
\end{tabular}

Table 5. Results of Squared multiple correlations

\begin{tabular}{|c|c|c|}
\hline Factor & Item & Squared Multiple Correlations \\
\hline \multicolumn{3}{|l|}{ CSR image (CSR) } \\
\hline & $\operatorname{csr} 2$ & .667 \\
\hline & $\operatorname{csr} 3$ & .642 \\
\hline & $\operatorname{csr} 4$ & .881 \\
\hline \multirow[t]{4}{*}{ C-C identification (CCID) } & & .300 \\
\hline & cci3 & .855 \\
\hline & cci4 & .785 \\
\hline & cci5 & .652 \\
\hline \multirow[t]{4}{*}{ Brand prestige (BPR) } & & .329 \\
\hline & bpr1 & .640 \\
\hline & bpr2 & .805 \\
\hline & bpr3 & .508 \\
\hline \multirow[t]{4}{*}{ Purchase Intention (PIN) } & & .804 \\
\hline & $\operatorname{pin} 1$ & .693 \\
\hline & $\operatorname{pin} 2$ & .598 \\
\hline & pin 3 & .748 \\
\hline
\end{tabular}

The hypotheses of this study were tested using SEM estimation. Table 6 shown the standardized coefficients for the structural relations tested, contained the direct, indirect, and total effect and the levels of signification. Our results exhibited that the effect of CSR image on brand prestige were statistically significant $(\beta=.57, \mathrm{p}<.01)$, thus validating $\mathrm{H} 1$. The effect of CSR image on consumer-company identification was significant and direct ( $\beta$ $=.18, \mathrm{p}<.05)$, which supports $\mathrm{H} 2$. The effect of the CSR image on purchase intention was insignificant $(\beta=.02$, $\mathrm{p}>.05$ ), and thus, $\mathrm{H} 3$ is rejected. The effect of brand prestige on consumer-company identification was significant $(\beta=.43, p<.01)$, which supports $H 4$. The effect of brand prestige on purchase intention was insignificant $(\beta=$ $-.03, \mathrm{p}>.05)$, and thus, H5 is rejected. Finally, the consumer-company identification positively affected purchase intention $(\beta=.90, p<.01)$, thereby supporting H6. Our results revealed that consumer-company identification partially mediated the effect of CSR image on purchase intention. The consumer-company identification (the level of indirect effect $=.245, \mathrm{p}<.05$ ) positively mediated the relationship.

Table 6. Results of hypotheses test (indirect effect and total effect)

\begin{tabular}{|c|c|c|c|c|}
\hline \multirow{2}{*}{ Hypothesis paths } & \multicolumn{3}{|c|}{ Standardized coefficient } & \multirow{2}{*}{ Results } \\
\hline & Direct effect & Indirect effect & Total effect & \\
\hline $\mathrm{H} 1: \quad \mathrm{BPR} \leftarrow \mathrm{CSR}$ & $.573 * *$ & .000 & .573 & Supported \\
\hline $\mathrm{H} 2: \quad \mathrm{CCID} \leftarrow \mathrm{CSR}$ & $.176^{*}$ & $.245^{*}$ & .421 & Supported \\
\hline H3: $\quad \mathrm{PIN} \leftarrow \mathrm{CSR}$ & .017 & .365 & .383 & Rejected \\
\hline H4: $\quad$ CCID $\leftarrow$ BPR & $.427 * * *$ & .000 & .427 & Supported \\
\hline H5: $\mathrm{PIN} \leftarrow \mathrm{BPR}$ & -.026 & .000 & .360 & Rejected \\
\hline H6: $\quad$ PIN $\leftarrow$ CCID & $.903 * * *$ & .000 & .903 & Supported \\
\hline
\end{tabular}

${ }^{*} p<.05,{ }^{* *} p<.01$. 


\section{Discussion and Conclusions}

This study proposed a model of CSR image, consumer-company identification, brand prestige, and purchase intention derived from previous studies. The hypotheses were tested using SEM and the goodness-of-fit of the overall model. All the models exhibited adequate fit in this study. Findings and hypotheses are discussed as follows.

First, hypothesis 1 proposes that CSR image has a positive influence on brand prestige, which was supported. This finding ties in with earlier work by Pomering and Johnson (2009). Also, hypothesis 2 proposes that CSR image has a positive influence on consumer-company identification, which was supported. This is consistent with earlier research by Lii and Lee (2012). However, hypothesis 3 proposes that CSR image has a positive influence on consumer's purchase intention, which was rejected. The finding is differentiated from the research by Johan and Ulf (2007). There are a number of possible explanations for this result. First explanation for CSR image cannot affect consumer's purchase intention is the fact that consumers positive CSR attitude may not transferred into purchase behavior (Oberseder et al., 2011). The second explanation for this could be that young consumers attach little importance to CSR. The last explanation is that the company may not promote their CSR achievements zealously to consumers.

Second, hypothesis 4 proposes that brand prestige has a positive influence on consumer-company identification, which was supported. This finding ties in with earlier work by Kuenzel and Halliday (2008). However, hypothesis 5 proposes that brand prestige has a positive influence on consumer's purchase intention, which was rejected. The finding is differentiated from the research by Tseng and Chen (2008). A partial explanation for this may lie in the fact that the target brand we chose was a foreign brand which may not attract consumers.

Finally, hypothesis 6 proposes that consumer-company identification has a positive influence on consumer's purchase intention, which was supported. This is consistent with earlier research by $\mathrm{Wu}$ and Tsai (2007). Furthermore, the results confirm that consumer-company identification mediates the effect of CSR image on consumers' purchase intention. In conclusion, CSR image creates consumers' identification with the company, which may enhance consumers' purchase intention.

\section{References}

Baek, T. H., Kim, J., \& Yu, J. H. (2010). The differential roles of brand credibility and brand prestige in consumer brand choice. Psychology \& Marketing, 27(7), 662-678. http://dx.doi.org/10.1002/mar.20350

Bhattacharya, C. B., \& Sen, S. (2003). Consumer-company identification: A framework for understanding consumers' relationships with companies. Journal of Marketing, 67(2), 76-88. http://www.jstor.org/stable/30040524

Bigne-Alcaniz, E., Curras-Perez, R., Ruiz-Mafe, C., \& Sanz-Bla, S. (2010). Consumer behavioural intentions in cause-related marketing. The role of identification and social cause involvement. International Review on Public and Nonprofit Marketing, 7(2), 127-143. http://dx.doi.org/10.1007/s12208-010-0053-6

Carroll, A. B., \& Shabana, K. M. (2010). The business case for corporate social responsibility: A review of concepts, research and practice. International Journal of Management Reviews, 12(1), 85-105. http://dx.doi.org/10.1111/j.1468-2370.2009.00275.x

Curras-Perez, R., Bigne-Alcaniz, E., \& Alvarado-Herrera, A. (2009). The role of self-definitional principles in consumer identification with a socially responsible company. Journal of Business Ethics, 89(4), 547-564. http://dx.doi.org/10.1007/s10551-008-0016-6

Davies, I. A., Lee, Z., \& Ahonkhai, I. (2012). Do consumers care about ethical-luxury? Journal of Business Ethics, 106(1), 37-51. http://dx.doi.org/10.1007/s10551-011-1071-y

Einwiller, S. A., Fedorikhin, A., Johnson, A. R., \& Kamins, M. A. (2006). Enough is enough! When identification no longer prevents negative corporate associations. Journal of the Academy of Marketing Science, 34(2), 185-194. http://dx.doi.org/10.1177/0092070305284983

Elbedweihy, A. M., \& Jayawardhena, C. (2014). Consumer-brand identification: A social identity based review $\begin{array}{llll}\text { and } & \text { research } & \text { Review, } & \text { 14(2), }\end{array}$ http://dx.doi.org/10.1362/146934714X14024778816995

Grimmer, M., \& Bingham, T. (2013). Company environmental performance and consumer purchase intentions. Journal of Business Research, 66(10), 1945-1953. http://dx.doi.org/10.1016/j.jbusres.2013.02.017

Helm, S. (2011). Employees' awareness of their impact on corporate reputation. Journal of Business Research, 
64(7), 657-663. http://dx.doi.org/10.1016/j.jbusres.2010.09.001

Hoffmann, S., \& Hutter, K. (2012). Carrotmob as a new form of ethical consumption. The nature of the concept and avenues for future research. Journal of Consumer Policy, 35(2), 215-236. http://dx.doi.org/10.1007/s10603-011-9185-2

Jeong, H. J., Paek, H. J., \& Lee, M. (2013). Corporate social responsibility effects on social network sites. Journal of Business Research, 66(10), 1889-1895. http://dx.doi.org/10.1016/j.jbusres.2013.02.010

Johan, A., \& Ulf, J. (2007). Corporate social responsibility and the positioning of grocery brands: An exploratory study of retailer and manufacturer brands at point of purchase. International Journal of Retail \& Distribution Management, 35(10), 835-856. http://dx.doi.org/10.1108/09590550710820702

Kuenzel, S., \& Halliday, S. V. (2008). Investigating antecedents and consequences of brand identification. Journal of Product \& Brand Management, 17(5), 293-304. http://dx.doi.org/10.1108/10610420810896059

Kuenzel, S., \& Halliday, S. V. (2010). The chain of effects from reputation and brand personality congruence to brand loyalty: The role of brand identification. Journal of Targeting, Measurement and Analysis for Marketing, 18, 167-176. http://dx.doi.org/10.1057/jt.2010.15

Lai, C. S., Chiu, C. J., Yang, C. F., \& Pai, D. C. (2010). The effects of corporate social responsibility on brand performance: The mediating effect of industrial brand equity and corporate reputation. Journal of Business Ethics, 95(3), 457-469. http://dx.doi.org/10.1007/s10551-010-0433-1

Lee, J., \& Lee, Y. (2015). The interactions of CSR, self-congruity and purchase intention among Chinese consumers. Australasian Marketing Journal, 23(1), 19-26. http://dx.doi.org/10.1016/j.ausmj.2015.01.003

Lee, K. H., \& Shin, D. (2010). Consumers' responses to CSR activities: The linkage between increased awareness and purchase intention. Public Relations Review, 36(2), 193-195. http://dx.doi.org/10.1016/j.pubrev.2009.10.014

Lee, P. K. C., Lau, A. K. W., \& Cheng, T. C. E. (2013). Employee rights protection and financial performance. Journal of Business Research, 66(10), 1861-1869. http://dx.doi.org/10.1016/j.jbusres.2013.02.007

Lii, Y. S., \& Lee, M. (2012). Doing right leads to doing well: When the type of CSR and reputation interact to affect consumer evaluations of the firm. Journal of Business Ethics, 105(1), 69-81. http://dx.doi.org/10.1007/s10551-011-0948-0

Mael, F., \& Ashforth, B. E. (1992). Alumni and their alma mater: A partial test of the reformulated model of organizational identification. Journal of Organizational Behavior, 13(2), 103-123. http://dx.doi.org/10.1002/job.4030130202

Malik, M. (2015). Value-enhancing capabilities of CSR: A brief review of contemporary literature. Journal of Business Ethics, 127(2), 419-438. http://dx.doi.org/10.1007/s10551-014-2051-9

Marin, L., \& Ruiz, S. (2007). “I Need You Too!” Corporate identity attractiveness for consumers and the role of social responsibility. Journal of Business Ethics, 71(3), 245-260. http://dx.doi.org/10.1007/s10551-006-9137-y

Mohr, L. A., \& Webb, D. J. (2005). The effects of corporate social responsibility and price on consumer $\begin{array}{lllll}\text { responses. } & \text { Journal }\end{array}$ http://dx.doi.org/10.1111/j.1745-6606.2005.00006.x

Mohr, L. A., Webb, D. J., \& Harris, K. E. (2001). Do consumers expect companies to be socially responsible? The impact of corporate social responsibility on buying behavior. Journal of Consumer Affairs, 35(1), 45-72. http://dx.doi.org/10.1111/j.1745-6606.2001.tb00102.x

Moslehpour, M., Pham, V. K., \& Yumnu, S. (2014). The mediating effect of quality and prestige on the relationship between brand globalness and purchase likelihood of HTC mobile phone. Research in Business and Management, 7(1), 94-108. http://dx.doi.org/10.5539/ibr.v7n1p94

Oberseder, M., Schlegelmilch, B. B., \& Gruber, V. (2011). "Why don't consumers care about CSR?": A qualitative study exploring the role of CSR in consumption decisions. Journal of Business Ethics, 104(4), 449-460. http://dx.doi.org/10.1007/s10551-011-0925-7

Park, J., Lee, H., \& Kim, C. (2014). Corporate social responsibilities, consumer trust and corporate reputation: South Korean consumers' perspectives. Journal of Business Research, 67(3), 295-302. http://dx.doi.org/10.1016/j.jbusres.2013.05.016 
Perez, A., Rodriguez, I., \& Bosque, R. (2013). Measuring CSR image: Three studies to develop and to validate a reliable measurement tool. Journal of Business Ethics, 118(2), 265-286. http://dx.doi.org/10.1007/s10551-012-1588-8

Perez, R. C. (2009). Effects of perceived identity based on corporate social responsibility: The role of consumer identification with the company. Corporate Reputation Review, 12(2), 177-191. http://dx.doi.org/10.1057/crr.2009.12

Pomering, A., \& Johnson, L. W. (2009). Constructing a corporate social responsibility reputation using corporate image advertising. Australasian Marketing Journal, 17(2), 106-114. http://dx.doi.org/10.1016/j.ausmj.2009.05.006

Putrevu, S., \& Lord, K. R. (1994). Comparative and noncomparative advertising: Attitudinal effects under cognitive and affective involvement conditions. Journal of Advertising, 23(2), 77-91. http://www.jstor.org/stable/4188929

Saeidia, S. P., Sofiana, S., Saeidia, P., Saeidia, S. P., \& Saaeidi, S. A. (2015). How does corporate social responsibility contribute to firm financial performance? The mediating role of competitive advantage, reputation, and customer satisfaction. Journal of Business Research, 68(2), 341-350. http://dx.doi.org/10.1016/j.jbusres.2014.06.024

Smith, N. C. (1995). Marketing ethics for the ethics era. Sloan Management Review, 36(4), 85-97.

Sweetin, V. H., Knowles, L. L., Summey, J. H., \& McQueen, K. S. (2013). Willingness-to-punish the corporate brand for corporate social irresponsibility. Journal of Business Research, 66(10), 1822-1830. http://dx.doi.org/10.1016/j.jbusres.2013.02.003

Tarnanidis, T., Owusu-Frimpong, N., Nwankwo, S., \& Omar, M. (2015). Why we buy? Modeling consumer selection of referents. Journal of Retailing and Consumer Services, 22, 24-36. http://dx.doi.org/10.1016/j.jretconser.2014.09.004

Tseng, Y. M., \& Chen, H. C. (2008). The factors for purchase intention and establishment of global perception of brand. Marketing Review, 5(4), 451-480.

Wu, W. Y., \& Tsai, C. H. (2007). The empirical study of CRM: Consumer-company identification and purchase intention in the direct selling industry. International Journal of Commerce and Management, 17(3), 194-210. http://dx.doi.org/10.1108/10569210710833617

\section{Copyrights}

Copyright for this article is retained by the author(s), with first publication rights granted to the journal.

This is an open-access article distributed under the terms and conditions of the Creative Commons Attribution license (http://creativecommons.org/licenses/by/3.0/). 